Newfoundland and Labrador Studies

\title{
Steven High, ed. Occupied St. John's: A Social History of a City at War, 1939-1945.
}

\section{Bonnie White}

Volume 29, Number 1, Spring 2014

URI: https://id.erudit.org/iderudit/1062249ar

DOI: https://doi.org/10.7202/1062249ar

See table of contents

Publisher(s)

Faculty of Arts, Memorial University

\section{ISSN}

1719-1726 (print)

1715-1430 (digital)

Explore this journal

Cite this review

White, B. (2014). Review of [Steven High, ed. Occupied St. John's: A Social History of a City at War, 1939-1945.] Newfoundland and Labrador Studies, 29(1). https://doi.org/10.7202/1062249ar viewed online.

https://apropos.erudit.org/en/users/policy-on-use/ 


\section{Reviews}

Steven High, ed. Occupied St. John's: A Social History of a City at War, 1939-1945. Montreal and Kingston: McGill-Queen's University Press, 2010.

ISBN 978-0-7735-3750-7

This edited collection of seven essays makes an important contribution to the growing body of literature that re-examines the impact of war on local communities. The essays are organized thematically and focus on the transformation of the city under wartime conditions, the war's impact on children, culture, and local institutions, and the global and strategic place of St. John's in the mid-twentieth century. A generous introduction by Steven High ties the topics together and provides necessary context for the individual essays. The introduction also offers a transnational perspective to the reader that places St. John's at the centre of discussions regarding shifting power relations during the war, as well as competing visions of modernity, empire, state formation, economic development, and cultural homogeneity. While stressing the strategic value of Newfoundland, the contributors to Occupied St. John's examine the political, social, and economic exchanges that took place between Newfoundlanders and "foreigners" who occupied the country between 1940 and 1945.

Studies of Newfoundland at war tend towards a military perspective, primarily focusing on the island's strategic location and the vital role played by naval convoys and the threat posed by German U-boats to North America's initially undefended coastline. Moving away from an American-centric perspective, Occupied St. John's revises accepted assumptions about the undesirability of shabbily dressed and inebriated Canadians, whose rowdy behaviours were a nuisance to the residents of St. John's, to present a more positive narrative that carefully contextualizes Canada's wartime relationship with the city. Christopher Sharpe and A.J. Shawyer, in the first chapter, summarize the transformation of the city's landscape, including the harbour, which the authors describe as the "city's lifeblood." With limited means, the government of Newfoundland committed itself to the war effort and put St. John's on a war footing in September 1939. It was the fall of France in June 1940, however, that confirmed the role of St. John's in the war and necessitated major changes to the city's geographic configuration. The war affixed the city with strategic value, but also upset social and economic contracts that predated the war. Paul Collins, in his essay, reinforces the transformative momentum of the war in his discussion of the St. John's harbour.

Part Two begins with Barbara Lorenzkowski's essay on "The Children's War." Basing her study on oral interviews, Lorenzkowski moves attention away 
from the schools and towards the family, church, and streets that informed childhood experiences. This essay provides a more complete image of the city's sights, sounds, and architecture and concludes that boys and girls appropriated different spaces within the city, but warns against a delineated gender separation. Children who were eager to experience the war occupied the physical environment of the city that became a domestic "war zone," closing the gap between the war and home fronts. Steven High's essay, "Rethinking the Friendly Invasion," looks at the gendered nature of the war and deconstructs the myth that marriages between Newfoundland women and American soldiers were common. Jeff Webb, in "Gate Keeping and Newfoundland Popular Culture," refutes the common belief that Newfoundland's cultural modernization came as a result of the American invasion. Stressing continuity over change, Webb concludes that this modernization predated the war, although American cultural influences were intensified with the arrival of Hollywood stars and USO clubs. Even so, military authorities and civic leaders faced similar challenges in terms of shaping engagement with the city for servicemen and local residents. Gillian Poulter and Douglas Baldwin's chapter on Mona Wilson and the Canadian Red Cross is not only a testament to Wilson's unending work, but offers commentary on the social conditions of the city, citing the persistent poverty, the shabbiness of dwellings, and the absence of central heating in many homes, conditions that did not diminish the willingness of Newfoundlanders to extend their homes and city to foreigners.

The conclusion, by Ken Coates and William R. Morrison, stresses the global nature of the city's wartime experience. Coates and Morrison ask important interpretive questions about how historians define or measure change, what the agents of change are, and how modifications to "space and place" impact local structures and transnational connections. The withdrawal of American and Canadian servicemen from the city and the economic depression raised new questions about government, social control, and civic identity.

Thematically, the organization of each chapter is redundant at times, but such redundancy would be difficult to avoid, given the thematic choices. The repetition, however, presents both an opportunity and a challenge to the book's authors. On the one hand, the narrative is contextualized and reiterated in each chapter, thus providing continuity and rhythmic readability. On the other hand, there is a lack of contextual analysis, in terms of both the period covered and the interactions between Newfoundlanders and foreign occupiers. Nevertheless, Occupied St. John's demonstrates that previous arguments about the separation of the war and home fronts need to be re-evaluated, as do assumptions 


\section{Reviews}

about how Newfoundlanders perceived their Canadian visitors and Confederation, although this last point is hinted at more than explicitly discussed. Anxieties about nationhood and foreign interactions that sought to place Newfoundland in a subservient and dependent role are also drawn to the surface and the authors present a balanced argument regarding the Newfoundland government's ability to meet residents' wartime needs and contribute to an international war. The oral testimonies of more than 50 Newfoundlanders who lived through the period add a personal touch to the narrative and refresh the authors' central argument that the war did not produce a clear separation between the home and war fronts. The book is visually stunning - with more than 100 photographs - and well researched, and will appeal to both the general public and undergraduates.

Bonnie White

St. Francis Xavier University

Mark Callanan and James Langer, eds. The Breakwater Book of Contemporary Newfoundland Poetry. St. John's: Breakwater Books, 2013.

ISBN 978-1-55081-408-8

The editors of The Breakwater Book of Contemporary Newfoundland Poetry owe me a night's sleep. I began reading the collection late one night and upon completing it early in the morning, went to my bookshelf and returned with Tom Dawe's In Hardy Country, Michael Crummey's Hard Light, John Steffler's The Grey Islands, and Agnes Walsh's Going Around with Bachelors. As the sun was rising, I had pilfered my daughter's collection and was reading Al Pittman's Down by Jim Long's Stage. Soon after, sleep-deprived but poetry-enriched, I was online purchasing works by Ken Babstock, Richard Greene, and Sue Sinclair. If an anthology such as this is meant to whet the reader's appetite, then editors Mark Callanan and James Langer do a fine job setting the table. The Breakwater Book of Contemporary Newfoundland Poetry is a perfect introductory collection for casual or uninitiated readers, a comprehensive enough text for students and teachers, and a slender, portable book for those who prefer not to travel without the best that Newfoundland poetry has to offer. And unlike 